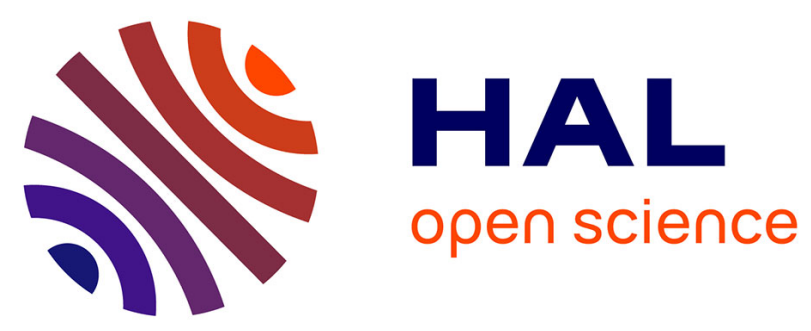

\title{
Water reservoirs, irrigation and sedimentation in Central Asia: a first-cut assessment for Uzbekistan
}

Shavkat Rakhmatullaev, Frédéric Huneau, Hélène Celle-Jeanton, Philippe Le Coustumer, Mikael Motelica-Heino, Masharif Bakiev

\section{To cite this version:}

Shavkat Rakhmatullaev, Frédéric Huneau, Hélène Celle-Jeanton, Philippe Le Coustumer, Mikael Motelica-Heino, et al.. Water reservoirs, irrigation and sedimentation in Central Asia: a first-cut assessment for Uzbekistan. Environmental Earth Sciences, 2013, 68 (4), pp.985-998. 10.1007/s12665012-1802-0 . insu-00723243

HAL Id: insu-00723243

https://hal-insu.archives-ouvertes.fr/insu-00723243

Submitted on 10 Dec 2013

HAL is a multi-disciplinary open access archive for the deposit and dissemination of scientific research documents, whether they are published or not. The documents may come from teaching and research institutions in France or abroad, or from public or private research centers.
L'archive ouverte pluridisciplinaire HAL, est destinée au dépôt et à la diffusion de documents scientifiques de niveau recherche, publiés ou non, émanant des établissements d'enseignement et de recherche français ou étrangers, des laboratoires publics ou privés. 


\section{WATER RESERVOIRS, IRRIGATION AND SEDIMENTATION IN \\ CENTRAL ASIA: A FIRST-CUT ASSESSMENT FOR UZBEKISTAN}

Shavkat RAKHMATULLAEV ${ }^{1,2,3}$, Frédéric HUNEAU ${ }^{2,3 *}$, Philippe LE COUSTUMER ${ }^{2,3}$, Mikael MOTELICA-HEINO ${ }^{4}$, Masharif BAKIEV ${ }^{1}$

${ }^{1}$ Tashkent Institute of Irrigation and Melioration, Hydraulic Engineering Faculty, 39 Kary Niyazov Street, Tashkent, 100000, Uzbekistan

${ }^{2}$ Université de Bordeaux, UFR des Sciences de la Terre et de la Mer, B18, avenue des Facultés, 33405 Talence, France

${ }^{3}$ EA4592 Géoressources \& Environnement, Institut EGID, 1 allée F. Daguin, 33607 Pessac, France

${ }^{4}$ Université d'Orléans, CNRS/INSU Institut des Sciences de la Terre d'Orléans - UMR 6113 Campus Géosciences, 1A rue de la Férollerie, 41071 Orléans, France

*Contact author:

Dr. Frédéric HUNEAU, Université de Bordeaux, UFR des Sciences de la Terre et de la Mer, B18, avenue des Facultés, 33405 Talence, France

Email: frederic.huneau@u-bordeaux 1.fr ; Tel: +33.5.40.00.88.41 


\section{Abstract}

Water reservoirs play an important role in areas with limited and erratic precipitation where water is stored and re-distributed later for different purposes. Irrigation is primarily a major water consumer in arid countries of Central Asia for the economic development, employment and food security of the region. The major rivers of Central Asia (e.g. Amu Darya, Syr Darya, and Zerafshan) are turbid watercourses. Sedimentation reduces the main reservoir asset i.e. its volume capacity. In addition, vast territories of the region's countries have been transformed for agriculture to grow water intensive crops such as cotton, rice and wheat during the Soviet Union that dramatically accelerated soil erosion by water and wind. Thus many man-made water reservoirs are affected by high sedimentation rates. Moreover, uneven spatial and temporal water resources and a Soviet inherited unified hydraulic infrastructure have raised transboundary reservoir management issues over water resources allocation among the countries in the region such as Kyrgyzstan, Tajikistan, Kazakhstan, Uzbekistan and Turkmenistan. The rivers such as Syr Darya and Amu Darya are already regulated by more than $78 \%$ and $94 \%$ respectively and attempts for new reservoir projects upstream raises increased concerns of the downstream countries (e.g. the Rogun hydropower station in Tajikistan and the Toktogul reservoir in Kyrgyzstan). For instance the uncoordinated use of reservoirs has caused the Arnasai lake problem in Uzbekistan with environmental, material damage and social unrest.

The aim of this paper is first to review the present conditions and the role of man-made water reservoirs for irrigation in Central Asia with special focus on Uzbekistan, second to document past and current reservoir sedimentation conditions in Uzbekistan and third to discuss research carried out by Soviet and present time local research community in the domain of erosion and sedimentation in the region.

Keywords: water management, erosion, sedimentation rate, water reservoirs, Central Asia 


\section{Introduction}

Due to their climatic characteristics, economic development strategies and geopolitical situation, Central Asian (CA) countries have been experiencing an everlasting competition over water resources. Mostly arid, these agrarian countries pursue their own development and integration into the global community through expanding irrigated lands, growing cash crops such as rice and wheat for meeting their domestic food security but also to export a large part of some productions such as cotton (Rakhmatullaev et al., 2009 and 2011).

Water reservoirs created by dam construction on rivers have played an important role for societies around the globe throughout their history by regulating floods, generating hydropower, and re-distributing the river flow for irrigation. Dams on rivers induce both river flow and sediment flux fragmentation which causes accelerated accumulation of sediments (Morris and Fan, 1998; Palmieri et al., 2001; Syvitski, 2003; Sternberg, 2006; Walling, 2006). Sedimentation is a natural geomorphologic process but human interference increases its rates. Sedimentation reduces the main reservoir asset i.e. its volume capacity over time due to the feeding rivers. Hence, the utility of a reservoir diminishes as its volume capacity is reduced (Karaushev, 1977; Skrylnikov et al., 1987; Mahmood, 1987; Annandale, 1998; World Commission on Dams (WCD), 2000; International Commission on Large Dams (ICOLD), 2008; World Association for Sedimentation and Erosion Research (WASER), 2008).

It is reported that an annual average $0.5-1 \%$ loss of volume capacities of small and large reservoirs is observed due to sedimentation in the world. It is estimated that such losses of storage capacities per year are worth billion US\$ and if such a scenario continues, about $25 \%$ of the world reservoir total volume capacity will be vanished over the next 25-50 years (Mahmood, 1987; WCD, 2000). Palmieri et al. (2003) reports that the loss in volume capacity requires an annual replacement cost of 13 billion US\$. Recent estimates are even more dramatic. For instance Yang (2003) reports that the overall annual loss rate of reservoir volume capacity due to sedimentation is estimated to be 1 to $2 \%$ of the total volume capacity. Moreover, Naisen and 
Lingyan (1998) reports that the average annual loss in volume capacity reaches $2.3 \%$ in China, being the highest in the world.

Globally, more than $50 \%$ of the basin-scale sediment fluxes in regulated basins are potentially trapped in artificial impoundments, with a discharge-weighted sediment trapping of about $30 \%$ due to large reservoirs and an additional contribution of about $23 \%$ from small reservoirs (Vörösmarty et al., 2003).

A reduced reservoir volume capacity diminishes the flow regulation for an assured water supply for irrigation, industrial activities and municipalities downstream. Sedimentation triggers operation and maintenance issues coupled with economic feasibility of the project, environmental concerns and social aspects (Lapshenkov, 1959; Bruk, 1985; Evrard, 1985; Morris and Fan, 1998; McPherson and Harmon, 1998; United States Army Corps of Engineers (USACE), 2001; Vörösmarty et al., 2003; International Hydrographic Organization (IHO), 2005). Moreover the deterioration of water quality in reservoirs can be a major issue with increasing levels of various contaminants from agriculture, industry, and natural sources whether organic (pesticides, PCBs, PAHs) or inorganic (heavy metals) (WCD, 2000; ICOLD, 2008; Gadalia et al., 2005, Gadalia and Motelica, 2008).

Downstream effects of sedimentation include channel narrowing, reduction in braiding and associated loss of ecosystem complexity, river bed erosion and a reduction in the overbank flooding that is critical to many riparian species (Brandt, 2000; Wohl and Rathburn, 2003; Syvitski, 2003; Sternberg, 2006; Walling, 2006). Dam cavitation and abrasion of conduits, valves, sluice gates and hydropower turbines dramatically impact the hydraulic facilities and structures (USACE, 2001; IHO, 2005). Moreover social aspects can also be the unattractiveness for tourism and the loss of recreation opportunities (WCD, 2000; Knoblauch, 2006).

After the fundamental and extremely fast political transformation of the whole region (collapse of the Former Soviet Union (FSU) and emergence of National States), the unified physical hydraulic infrastructure and its management have been fragmented. For instance, each 
year the CA countries negotiate the water allocation from transboundary reservoirs such as the Toktogul reservoir in Kyrgyzstan, which has an explicit impact on the management of the entire Syr Darya River system. This large reservoir works in both irrigation-energy regimes but downstream States favoring the irrigation operation mode over energy production. New water reservoirs are being planed upstream for the regulation of the river flow and to increase the hydropower generation opportunities in Tajikistan and Afghanistan on the Amu Darya River system and in Kyrgyzstan on the Syr Darya River system respectively.

Under the market-oriented conditions, financial constrains have resulted in the decrease of government assisted rehabilitation and maintenance works of hydraulic infrastructures programs by several folds despite any water reservoirs have been constructed more than 20-25 years ago and need substantial rehabilitation. For instance the majority of reservoirs have been silted by sediments. Recent drought years urged authorities to re-estimate the water availability in reservoirs of Uzbekistan for the sustainable use of the natural resources and hydraulic infrastructure.

Thus there is urgency to adopt an innovative approach in bathymetric surveys for estimation of reservoir volume capacities due to sedimentation. New technologies such as GPS (Global Positioning System), acoustic depth measurement systems and contour mapping software have proved to increase geo-referenced data, improve the accuracy of data and most importantly substantially decrease the expenses of the bathymetric studies. In fact, since 2001 new geoinformation technologies have been used in bathymetric surveys in Uzbekistan. Last but not least there is limited information on water reservoirs in CA region in the international scientific literature.

Thus the first objective of this paper is to present the first-cut assessment on water reservoirs, their role for irrigated agriculture and the transboundary aspects of water reservoir management in CA region. The second objective is to discuss the current reservoir sedimentation conditions, extent and characteristics of man-made reservoirs in Uzbekistan. The third objective 
is to briefly overview some research on sedimentation and erosion carried out in the region by Soviet and local research communities.

\section{Irrigation and water reservoirs in Central Asia}

With an annual rainfall of $100-300 \mathrm{~mm}$ and a mean evaporation of 1600-2200 mm, Uzbekistan has a continental climate of the dry mid-latitude desert, characterized by hot summers and cold winters (Shultz, 1949; UNEP, 2005; FAO, 2007). Its climate is largely arid and its water resources are unevenly distributed both in space and time. There is a strong dependency on winter and spring rains and snowmelt from the Tien Shen and Pamir mountains.. In fact these mountains are major contributors to the watersheds of CA countries (World Bank, 2005).

Thus the agricultural production of the region is predominantly based on irrigation, which makes irrigation water supply and management the major factors limiting crop yields in the region (Ibragimov et al., 2007). The complexity of water resource relations in this region is related to the soviet inheritance of interconnected hydraulic infrastructure and to the transboundary origin of water resources.

Interstate Commission on Water Coordination (2004) reports that in Central Asia, for the period of 1960-1990, the total annual water intake was about $60.6 \mathrm{~km}^{3}$ in 1960 and $116.2 \mathrm{~km}^{3}$ in 1990. Thus there was about a two fold increase in 30 years. In contrast the population of the region has increased by 2.7 folds and the area under irrigation increased by 1.7 fold.

Man-made reservoirs play a particularly important role where natural precipitation is erratic or seasonal because they store water during wet periods to make it available during dry periods. The role of water reservoirs has become very important in periods of water scarcity which are being documented in the region. World Bank (2005) reports that in drought year of 2000-2001 river flows dropped to between $35 \%$ and $40 \%$ below average levels. For example, the irrigation water scarcity became progressively worse particularly in downstream areas in the 
north of Uzbekistan. Economic damage was in order of hundreds of millions of US dollars with implication to population livelihoods and environmental issues. As recent research shows, a decreasing trend is evident in the Amu Darya discharge; in fact the discharge of Syr Darya did not decrease since 1985 (Nezlin et al., 2004).

The first water reservoirs of the Central Asian region have been constructed as early as in the X-XI centuries (Avakyan et al., 1987; Nikitin, 1991). The era of massive water reservoir construction begun in the late 1900s. For example, the Gindikush (Turkmenistan) reservoir was built in the Basin of the Murgab River in 1896 with a total volume capacity of $13 \mathrm{Mm}^{3}$ and 65 $\mathrm{Mm}^{3}$ for the Sultanbent reservoirs in 1909-1910 (Irrigation of Uzbekistan, 1975; Skrylnikov et al., 1987). In 1940s several reservoirs have been constructed such as the Urtatokai reservoir in the Kassansai River Basin in Ferghana region and the Kattakurgan reservoir in the Zerafshan River Basin. For the last 30 years (from 1950 to 1980) more than 60 reservoirs have been constructed in the region (Table 1). Figure 1 depicts the schematic distribution of the main water reservoirs and their volume capacities in the $\mathrm{CA}$ region excluding reservoirs in central and northern region of Kazakhstan.

\subsection{Threats to water resources}

There are more than 290 water reservoirs in the Central Asia with a total volume capacity over $163 \mathrm{~km}^{3}$ that regulate more than $50 \%$ of the monthly regions river flow and the area occupied by reservoirs constitutes roughly $6 \%$ of the CA countries irrigated areas (Table 2) (Avakyan et al., 1987; Skrylnikov et al., 1987; Nikitin, 1991; FAO, 2007). The primary source for irrigation in the region is the surface flow from rivers and man-made reservoirs. For example, an average of about $30 \%$ of irrigation water is delivered from reservoirs, ranging as high as $54 \%$ in Turkmenistan and as low as $13 \%$ in Kyrgyzstan (UNEP, 2005; FAO, 2007). 
After the dissolution of FSU, the land-locked arid countries of CA region have directed their natural resources utilization towards economic development from previous planned to a market-oriented economy. Irrigated agriculture is the dominant sector of the economy in the CA countries, employing about $45 \%$ of the total population (World Bank, 2003; ICWC, 2004; IAMO, 2008; Abdullaev et al., 2009). This sector contributes to the region countries Gross Domestic Product (GDP) from 16 up to $30 \%$ with an average of $24 \%$ for the whole region (FAO, 2007). As a whole, $26 \%$ of the cultivated areas are irrigated, from $10 \%$ in Kazakhstan to over $99 \%$ in Turkmenistan. Thus $91 \%$ of the total water withdrawal is used for agricultural purposes in the region (Ximing et al., 2003; UNEP, 2005; Weinthal, 2006). Figure 2 shows the historical increase of irrigated lands in CA region for the last century. Over a period of 90 years (19132003) the areas under irrigation have increased by 3 times on average (Sattarov et al., 2006). This increase was due to a gigantic Soviet hydraulic program through construction of dams, irrigation canals, pumping stations and various hydraulic facilities.

Irrigation in CA region relies on a system of pumps and canals which is among the most complex in the world (O'Hara, 2000; Weinthal, 2006; UNDP, 2007). Cotton and wheat are the major crops followed by maize, vegetables and fruits. In Uzbekistan, which accounts for over half of the irrigated land in the CA region, it is estimated that about $70 \%$ of water is lost between the river and the crop, and poor drainage further exacerbates water management (World Bank, 2005).

Additionally there has been a general warming up in the CA countries on the order of 1-2 ${ }^{0} \mathrm{C}$ since the beginning of the $20^{\text {th }}$ century that might have a strong potential impact on the regional temperatures and precipitation regime but also on natural ecosystems and agricultural crops (Lioubimtseva et al., 2005). With drought and climate change in the region, water resources will be more stringent and transboundary management of hydraulic structures has to be developed in harmonic cooperation to meet current concerns for satisfying all involved parties. Khorst (2001) reports that according to the estimations made by the Uzbek Hydro- 
Meteorological Committee, the pessimistic scenarios of water resources transformations due to global warming and reduction of ice and snow accumulations in $\mathrm{CA}$ region would be the reduction of discharge by $15-20 \%$ and $20-30 \%$ for the Syr Darya River and the Amu Darya River respectively. The following case study illustrates the consequences of inappropriate management of transboundary reservoirs known as the "Arnasai Lake" problem.

\subsection{Case of the Arnasai Lake - Transboundary reservoir management}

For the regulation of the CAR rivers, hundreds of man-made water reservoirs were constructed to mitigate natural shortage of water resources (Figure 1). Competition for water resources is prioritized by the downstream countries (Uzbekistan, Turkmenistan and Kazakhstan) for irrigation whereas upstream countries (Tajikistan and Kyrgyzstan) use them mainly for hydropower generation (O'Hara, 2000; ICG, 2002; UNEP, 2005). There has been a serious conflict related to the water resource management of some hydraulic infrastructures like the Toktogul reservoir located in Kyrgyzstan in the recent post-soviet period (Figure 3) (ICG, 2002; Weinthal, 2006). This water storage infrastructure serves for the needs of the entire Syr Darya River basin. Its main purpose is to regulate and secure the Syr Darya River flow during the vegetation period (April-October). It was designed to release $8.5 \mathrm{~km}^{3}$ of water during the vegetation season and in order to restore the storage only $2.8 \mathrm{~km}^{3}$ during the non-vegetation season. However the situation has significantly changed due to the end of the FSU. At present, new independent states can hardly negotiate on proper water allocation quotas for irrigated agriculture in summer for downstream countries and electricity generation in winter for upstream countries (O’Hara, 2000; ICG, 2002; UNEP, 2005; Weinthal, 2006).

The following example vividly shows that catastrophic environmental, economic and social issues can be caused by an inappropriate use of transboundary water reservoir. This is the so called “Arnasai Lakes" problem (UNDP 2007). The Syr Darya river flow is regulated within a volume of about $34 \mathrm{~km}^{3}$ by the cascade reservoir of the Naryin-Syrdarya system. This system is 
arranged according to the following scheme (Figure 3), the Toktogul reservoir upstream (Kyrgyzstan) with a total volume capacity of more than $19.5 \mathrm{~km}^{3}$ is operated in an irrigationenergy production regime (UNDP, 2007). The two reservoirs of Charvak and Andijan (Uzbekistan) with a total volume capacities of $2.0 \mathrm{~km}^{3}$ and $1.9 \mathrm{~km}^{3}$ respectively are located downstream and the Kairakkum reservoir in Tajikistan, middle reach of the river with a total volume capacity of $4.2 \mathrm{~km}^{3}$ together with the Chardara reservoir in Kazakhstan with a total volume capacity of $5.7 \mathrm{~km}^{3}$ which closes the system and operates in irrigation mode for water users downstream.

In 1969 a catastrophic flood forced to discharge about $2.7 \mathrm{~km}^{3}$ from the Chardara reservoir to the Arnasai topographic depression creating here a huge new permanent lake. Until 1993 the Arnasai system, with a total area of 2,000 km², was stabilized, but from 1993, further releases from the Chardara reservoir caused a rise in the water level of $8.7 \mathrm{~m}$. By the summer of 2003, the total area of this lake system reached $3,491 \mathrm{~km}^{2}$ and today Arnasai is the largest system of lakes in Uzbekistan comprising the Aidarkul, Tuzkan, and Upper Arnasai lakes (UNDP, 2007).

Some experts argue that the creation of this lake system is favorable to the surrounding ecosystems and micro climate but it should be mentioned that as a result of the continuous water discharges in winter for hydropower generation, about 180,000 ha of land were flooded in the Jizzak and Navoi provinces of Uzbekistan. In addition, flooding has an impact on the local infrastructures resulting in the loss of tens of kilometers of roads, electric power lines, gas pipelines and other facilities. In addition, about 2,500 inhabitants of two settlements are at risk to lose their livelihoods because of flooding. The total damage is estimated to about 700 million US\$ (UNDP, 2007).

Recently, in 2008, Kazakhstan started to construct the Koksarai reservoir downstream of the Chardara reservoir as a countermeasure for flooding of its agricultural and settlement areas with a design capacity of about $3 \mathrm{~km}^{3}$ and a total dam length of more than $44.7 \mathrm{~km}$, cost is 
estimated about 100 million US\$. But is should be pointed out that the decision to construct this hydraulic structure is only on the initiative of Kazakhstan without consensus with Uzbekistan.

\section{Water resources, reservoirs and sedimentation in Uzbekistan}

\subsection{Water resources}

Uzbekistan is largely an arid region, where evaporation exceeds rainfall and annual precipitation is below $200 \mathrm{~mm}$ (UNDP, 2007). This means that agricultural production is impossible without irrigation. The streamflow is characterized by an extreme intra-annual variability and is also unevenly spatially distributed (Kazbekov et al., 2007; Rakhmatullaev et al., 2009). Two main river basins are found in Uzbekistan, the Amu Darya and the Syr Darya (Schlüter et al., 2005). The transboundary rivers Amu Darya and Syr Darya satisfy $82 \%$ of the total water demand for irrigation, whereas only $18 \%$ of the same demand is satisfied by the internal rivers Kashka Darya, Zerafshan and Surkhan Darya in Uzbekistan (Figure 3) (UNEP, 2005; UNDP, 2007; Rakhmatullaev et al., 2008a).

According to experts, the total amount of flow produced in the Amu Darya basin is estimated at $78.46 \mathrm{~km}^{3} /$ year and about $6 \%$ of the average total surface water resources of the Amu Darya river basin are generated within Uzbekistan (Crosa et al., 2006; UNEP, 2005; FAO, 2007). The Amu Darya River stretches from its source the Pyandj River to the Aral Sea over $2540 \mathrm{~km}$, including about $1000 \mathrm{~km}$ within the territory of Uzbekistan. The total amount of flow produced in the Syr Darya basin is estimated at $37.14 \mathrm{~km}^{3} /$ year and about $13 \%$ of the average surface water resources of the Syr Darya River basin, are generated within Uzbekistan (Nezlin et al., 2004; FAO, 2007; Rakhmatullaev et al., 2009). The total length of the Syr Darya River is $2800 \mathrm{~km}$, of which $2000 \mathrm{~km}$ flows through the territory of Uzbekistan. The long-term average runoff of the Zerafshan River is estimated to be $5.91 \mathrm{~km}^{3}$ and only $0.76 \mathrm{~km}^{3}$ of runoff is formed in Uzbekistan. The Zerafshan River starts in Tajikistan and the third largest river basin in Uzbekistan. Thus, the total water deficit in Uzbekistan is estimated to $2.5 \mathrm{~km}^{3} / \mathrm{year}$ in the Syr 
Darya river basin and between 1.5 to $3.0 \mathrm{~km}^{3}$ in the Amu Darya river basin depending on water availability in a particular year (O’Hara, 2000, Weinthal, 2006; UNDP, 2007; FAO, 2007).

The total cultivated land in Uzbekistan is estimated to be about 5.2 million ha, of which 4.2 million ha are irrigated (FAO, 2007). Figure 4 shows the evolution of the irrigated land area and of the specific water intake for irrigation during the last century. It illustrates the trends in the increase of the irrigated land and in specific water intake. As it can be seen the area of irrigated land will certainly increase in the future and the specific water intake will peak at $13,000 \mathrm{~m}^{3} /$ ha even in a foreseeable future (UNDP, 2007).

\subsection{Reservoirs}

At present time, approximately $90 \%$ of the water resources in Uzbekistan are used for irrigated agriculture. In fact water is withdrawn from the surface runoff by a system of 1130 pumping stations that irrigate over $50 \%$ of the total irrigated land, via a 22,300 $\mathrm{km}$ long network of inter-farm and main canals, and 42 water intake structures (with a capacity of $10-300 \mathrm{~m}^{3} / \mathrm{sec}$ ) (UNDP, 2007). In fact about $24 \%$ of irrigation water in Uzbekistan comes from water reservoirs (Figure 5).

This complex hydraulic infrastructure is financed and maintained by the government. However, with the transition period of Uzbekistan from a centralised to a market-oriented economy, financial flows have been reduced. For example, over a 10 years span (1991-2001) the government investment portfolio assigned for rehabilitation activities has decreased from $27 \%$ to $8 \%$, the capital investment to the water sector being reduced by 5 times (UNDP, 2007). This reduction in investment portfolio has further worsened the operation and maintenance of existing infrastructure and this particularly concerns water reservoirs.

The total number of man-made water reservoirs in Uzbekistan is 55 (Table 2) (UNDP, 2007; Rakhmatullaev et al., 2008b). The total gross volume capacity of all reservoirs is about 19 $\mathrm{km}^{3}$ and the useful volume capacity is about $14.5 \mathrm{~km}^{3}$ whereas the total surface area of reservoirs 
is estimated about $1450 \mathrm{~km}^{2}$. The average dam height is about $39 \mathrm{~m}$ with a maximum of $168 \mathrm{~m}$ (Tupalang reservoir) and a minimum of $11.5 \mathrm{~m}$ (Uchkyzyl reservoir). About 57\% of all reservoirs have a volume capacity about 1 to $50 \mathrm{Mm}^{3}$ but only five have a volume capacity of more than $1 \mathrm{~km}^{3}$. Moreover for the surface area, only eight reservoirs have a surface area greater than $50 \mathrm{~km}^{2}$. Table 3 gives the main characteristics of large water reservoirs in Uzbekistan. These nine major reservoirs constitute about $86 \%\left(16.8 \mathrm{~km}^{3}\right)$ of the total reservoir volume capacity and about $94 \%\left(1362 \mathrm{~km}^{2}\right)$ of the total surface area in Uzbekistan.

Almost $90 \%$ of all dams are used for irrigation purposes and only two for hydropower (Andijan and Charvak). The Amu Darya river is regulated by $78 \%$ whereas only by $94 \%$ for the Syr Darya river (UNEP, 2005; Rakhmatullaev et al., 2008a; UNDP, 2007). For example, all main run-on-the-river reservoirs for the regulation of the Amu Darya and Syr Darya river flows are located beyond the boundaries of Uzbekistan, with the exception of the Andijan, Tuyamuin, and Janubiy Surkhan reservoirs (Figure 3). Therefore Uzbekistan is vulnerable in terms of transboundary reservoir management for a sustainable water allocation. There are almost no sites left for the construction of new reservoirs. Thus it is a strategic importance to rationally calculate the available water resources in the existing reservoirs for assuring a guaranteed water supply for the agriculture, industry and municipalities.

The peak of dam construction is dated to the soviet period when its policy was aiming at expanding irrigated lands for the mass production of cotton. These impressive actions have resulted in a great increase in irrigated lands from 2.57 million ha in 1960 to 4.22 million ha by the late 1980's (UNDP, 2007). The dam construction is graphically illustrated in Figure 6. About $75 \%$ of dams were constructed in the 30-years period from 1961 to 1990 with $93 \%$ of a total reservoir capacity known as the "soviet period" (Rakhmatullaev and Le Coustumer, 2006; Rakhmatullaev et al., 2008b). After the 1990's just a few dams have been constructed mainly to finish the already initiated projects. At present time two dams are being constructed in Uzbekistan for securing water availability for the vegetation period. For example, for the 
mitigation of drought in the 2000-2001 years, the government of Uzbekistan in the Namangan province initiated the construction of the Rezaksai reservoir with a total capacity of $0.2 \mathrm{~km}^{3}$ in the perspective of increasing the water availability up to $0.66 \mathrm{~km}^{3}$.

\subsection{Sedimentation and erosion}

The environmental concerns related to land degradation are desertification, loss of biodiversity, land salinization and overgrazing of lands that can generate high rates of erosion and sedimentation (Tookey 2007; UNEP 2005; UNDP 2007).

The World Bank (2005) reports that the loss of vegetative cover on rain-fed and pasture lands in Uzbekistan has contributed to the severity of runoff, floods, landslides and drought when adverse weather events did occur. In Uzbekistan, the common forms of erosion are mainly wind and irrigation. In particular, wind erosion is dominant in desert regions of Khorezm, Bukhara and Karakalpakstan. According to Talipov (1992) the wind erosion is observed above a wind velocity of $15 \mathrm{~m} / \mathrm{s}$. Figure 7 depicts the percent of affected lands to different types of erosion in Uzbekistan. The erosion by water and irrigation has increased due to the improper irrigation methods and to the increase of irrigated areas on steep slopes. In addition, the main contributing factors are deforestation and overgrazing (UNESCO, 2000). Nowadays, wind erosion has dramatically decreased by $50 \%$ against 1980 s due to preventive action plans by vegetation strips around irrigated areas but the specific losses of humus layer over a season due to erosion can still reach 80 t/ha (UNDP, 2007). According to a recent study by the UNDP, around 0.8 million ha of land is subject to water erosion and more than 2.3 million ha suffered from wind erosion in Uzbekistan.

UNEP (2005) reports that about $75 \%$ of the total number of mudflows in the CA region has occurred in Uzbekistan. According to the World Resource Institute, the percentage of watershed basin affected by water-related erosion is about $5 \%$ for the CA region and for Uzbekistan (Revenga et al., 1998). Talopiv (1992) reports that the mean annual soil erosion by 
water is estimated to be between 100-150 tons/ha whereas its value varies from 25 to 50 tons/ha for gentle slopes to 500 tons/ha for steep slopes. To combat the erosion various mitigation measures have been used in Uzbekistan such as the implementation of vegetation strips, terracing on steep slopes, implementation of engineering erosion preventive structures and the application of conservation tillage techniques (Rakhmatullaev and Le Coustumer 2006; Rakhmatullaev et al. 2008b).

Smalley et al (2006) discusses the loess formation processes in eastern part of Uzbekistan near the capital of Tashkent. According to their arguments the hydrocollapse and water erosion are closely related and are controlled by the complex nature of the loess ground. Dust clouds in eastern Uzbekistan are largely loess related, but in the west dust material is raised from the drying Aral Sea bed; this is mainly composed of clay minerals agglomerated material and can carry on dangerous pollutants.

\subsection{Silting up of reservoirs}

According to the Uzbekistan Ministry of Agriculture and Water Resources (UzMAWR), 11 out of the 27 inspected reservoirs are almost completely silted up and at 5 other reservoirs the silt has almost reached the level of the outlet structures (UNDP, 2007).

In 2001 the Uzbek Bathymetric Center was established under the umbrella of UzMAWR, which is authorized for bathymetric surveys using new technology including GPS (Global Positioning System), depth measuring transducer CEEDUCER® of Bruttour International PTY Ltd. Bathymetric survey are then carried out from a moving boat using electronic depthsounding equipment in conjunction with GPS and an automatic data recorder CEEDUCER® with its base station located on the shoreline according to standards (McPherson and Harmon, 1998; USACE, 2001; IHO, 2005). GPS was used to determine the latitude and longitude for each depth measurement. Sounding equipment was used to measure depth from a transducer probe, operating at the frequency of $200 \mathrm{kHz}$ to the bed of the reservoir. Depths recorded by the 
sounder were measured at a fixed distance below the water surface (Bathymetric Center, 2003). The recorded depths and the constant value of the depth sounder were subtracted from the water surface elevation to obtain elevations of the reservoir bed. The depths were synchronized with the GPS data to determine the location of the probe as the boat traversed across the reservoir.

The center has performed bathymetric surveys in 16 reservoirs in Uzbekistan (Table 5) (Bathymetric Center, 2003). As it can be seen the total volume capacities and the dead storage capacities of all reservoirs have decreased by about $18 \%$ and $55 \%$ respectively on the average. For example, the dead volume capacities of 7 reservoirs decreased by more than $75 \%$. This is an alarming signal that in new future the sedimentation rates can be unprecedented with operation and maintenance issues.

\section{Research on reservoir sedimentation in the former Soviet Union}

In the area of fluvial morphology, erosion and sedimentation research, significant development was carried out in the FSU that greatly contributed to this domain of knowledge. It should be worth to discuss in brief the contributions of Russian speaking scholars in the domain of water reservoir sedimentation.

Sedimentation of engineering hydraulic structures, reservoirs, irrigation channels and their mitigation measures have been studied extensively by the Soviet and scientists of Uzbekistan. We have to mention the fundamental research works of the following authors: Altunin (1962), Avakyan (1987), Velikanov (1954), Vuglinskiy (1991), Ibad-Zade (1989), Karaushev (1969 and 1977), Popov (1977), Shamov (1939), Lapshenkov (1959); Uzbekistan scholars: Muhamedov (1976), Nikitin (1991), Skrylnikov (1987), Ismagilov (1997), Bakiev and others (Karaushev, 1977; Irrigation of Uzbekistan, 1975, Rakhmatullaev et al., 2008b).

Shvartsman (1994) reviews the common reservoir sedimentation computation methods based on the mean long-term annual sediment inflow of the river to the total reservoir volume used in FSU. It is known that the major contributing source of the reservoir sedimentation is 
suspended and bedload sediments carried out by streamflow and to less extent the bank erosion and eolian sediments carried out by wind from surrounding areas in the vicinity of the reservoir. According to the research of Skrylnikov (1987) this can contribute to about 3-6\% of the total sediment load.

The two main characteristics such as water exchange duration $\left(T_{c}\right)$ and sedimentation rate $\left(t_{c}\right)$ are first preliminary indexes used for reservoir sedimentation in the FSU.

The value of $T_{c}$ is expressed in years and determined from the following equation:

$$
T_{c}=W / V_{\text {in }}
$$

where: $W$ is the reservoir volume at full pool elevation $\left(\mathrm{m}^{3}\right)$ and $V_{\text {in }}$ is the mean annual long-term river inflow to the reservoir $\left(\mathrm{m}^{3} /\right.$ year $)$.

The value of $t_{c}$ is estimated from the following expression

$$
\boldsymbol{t}_{c}=W / V_{s}
$$

where: $W$ is the reservoir volume at full pool elevation $\left(\mathrm{m}^{3}\right)$ and $V_{s}$ is the mean annual long-term sediment inflow flux to the reservoir ( $\mathrm{m}^{3} /$ year).

Indeed the actual reservoir sedimentation always exceeds the value of estimated $t_{c}$ because of the part of sediments load discharged downstream. The abovementioned methods give only preliminary generalized assessment of reservoir sedimentation. Under the conditions of $T_{c}>0.02$ then the total reservoir sedimentation is estimated. For example, the first step is computation of $t_{c}$ value and if this value exceeds 200 years then this ought to be the potential reservoir operation period. In this case, the sediment accumulation volume in a specified number of years is calculated as a product of a mean annual sediment inflow load by the number of years. On the other hand, if the value of $t_{c}$ is less than 200 years then the reservoir sedimentation should be estimated taking into account the sediment discharged downstream. The following data should be available for use of abovementioned methods such as mean long-term water 
discharge, total sediment discharge of streamflow to the reservoir, morphological shapes of the streamflow and reservoir.

Bobravitskaya (2002) reviews the erosion and sediment yield models used in the FSU and outlines the major retrospective development in the domain of soil erosion studies, soil classification system, global and regional soil maps in the FSU and major soil erosion factors and processes with integration of various qualitative and quantitative assessment methods and models in particular.

Bobravitskaya and Zubkova (1997) comprehensively reviewed the estimation methods for determining annual suspended sediment yield in rivers that has been developed and still used in the countries of the FSU. There are about 24 major factors of anthropogenic origin that impact the sediment yield such as construction of hydraulic structures on riverine systems, land use on slopes, deforestation, irrigated agriculture, mining, fires and others. It is out of scope of the paper and for detailed discussion of methods used and developments in this area one should consult the abovementioned authors.

Ismagilov (1997) has first reviewed fluvial sediment transport estimation methods that are available from the international scientific community for the arid CAR. One can cite the first review papers by Golosov et al (2008) and Alekseevskiy et al (2008) for fluvial geomorphology sciences development in the FSU with principles and different methods used in this domain of research. The paper briefly overviews the major developments in erosion and sedimentation studies carried out in the CAR which have been transformed significantly due to the massive water resource development in the era of Soviet legacy. The early studies for examining channel deformations in reservoir basins in Uzbekistan have been documented in the 1950's with massive development of irrigation steppes and regulation of flow regimes in Uzbekistan (Irrigation of Uzbekistan, 1975).

In 1939 Shamov wrote a generalized monograph on reservoir sedimentation (Karaushev, 1969). He suggested a relatively simple approximate sedimentation calculation method that 
looks at the morphological characteristics of water body and sediment yield for examining the chronology of the reservoir sedimentation. In later periods, more detailed reservoir sedimentation calculation methods have been developed by various authors (Irrigation of Uzbekistan, 1975, Rakhmatullaev and Le Coustumer, 2006).

Skrylnikov et al. (1987) reports that Altunin (1962) has suggested that the reservoir sedimentation process can be subdivided into lake (free from sediments) and channel (concentrated with sediments) parts. In the process of sedimentation, the channel part advances onto the lake part and at the same time advances upstream, thus constructing supplemental dynamic reservoir storage (Irrigation of Uzbekistan, 1975).

Lapshenkov (1959) has proposed a more elaborated sedimentation estimation method that has proved to be correlated by field observations (Skrylnikov et al., 1987). Lapshenkov (1959) has also proposed an equation describing a linear relationship between the released sediment discharge and the volume of sediment accumulation for low head barrages based on quasi-laminar theory of sediment settling in sedimentation process.

The equation expresses the volume change in the reservoir over time:

$$
V_{t}=V_{o} x e^{s t}
$$

Where:

$V_{o}$ - is the maximum (upper limit) of sedimented volume (reservoir volume minus river channel volume at the end of the sedimentation period), $\mathrm{m}^{3}$

$\varepsilon$-the sedimentation characteristics depending on annual sediment yield (maximum volume that will be silted and initial level of sedimentation), $\mathrm{m}^{3}$

$t$ the period of reservoir operation in years.

For the calculations of the sediment distribution along the length of the reservoir Lapshenkov (1959) has suggested to use the above mentioned equation for any cross-section of a reservoir (changing $V_{o}$ and $\varepsilon$ ) and determine the sedimentation area as the difference in accumulation deposited in two adjusted cross-sections apart of $1 \mathrm{~m}$ between them. The 
Lapshenkov method was extensively used for the prediction and calculation of sedimentation rates in the design of many reservoirs in Central Asia and is considered as a standard.

The rate of reservoir sedimentation is characterized by $\varepsilon$ (clarification coefficient, i.e., the fraction of sediments that is retained in reservoir) which depends on the volume of the reservoirs, water discharge, sediment size distribution and turbidity. It is known that prior to the impoundment, the sediment carrying capacity of river is not altered and can therefore transport all sizes of sediments. The initial headwater volume capacity of reservoir $W_{i}$ includes the volume capacity of the river channel $\left(W_{r}\right)$ that transports all sediment fractions. $W_{r}$ is calculated by multiplying the cross-sectional area of the river channel by the length of the reach where hydraulic head is observed in headwater part of the reservoir. Prior to the impoundment there is no hydraulic head in headwater part of the reservoir thus $W_{i}$ equals to $W_{r}$ and the coefficient of clarification is zero. Therefore, under the conditions $W_{i} / W_{r}=1$, then $\varepsilon=0$, and when $W_{i} / W_{r}<1$, then $\varepsilon>0$. Skrylnikov et al. (1987) while analyzing the coefficient of water clarification has suggested to divide the sedimentation process into two phases: in the first phase full accumulation of sediments in reservoir occurs, characterized by a constant level of clarification $\varepsilon=95$ to $97 \%$, the second phase is observed when the reservoir storage decreases to the level of $W_{i}<7.7-W_{r}$, because of sedimentation processes, and is characterized by a rapid reduction of the clarification level (Skrylnikov et al., 1987; Rakhmatullaev et al., 2008b).

\section{Conclusion and Perspectives}

Uzbekistan which is located downstream of the two main rivers of Central Asia (Amu Darya and Syr Darya) experiences a water deficit allocation both in time and space for irrigation due to climatic conditions and the human induced water reservoir system. Agriculture based on irrigation is a dominant sector for employment, state foreign revenues and livelihood in Uzbekistan. Thus it is of paramount importance to accurately estimate the available water resources in reservoirs for an assured water allocation and sustainable management of the 
existing physical hydrological infrastructure. In fact almost the majority of reservoirs has lost their dead storage capacities due to sedimentation and in the next 20-30 years reservoirs will loss their functionality if mitigation measures are not undertaken.

The transboundary nature of the hydraulic engineering infrastructure systems of Uzbekistan gives a geopolitical dimension to the management and use of water reservoirs. The uneven distribution of water resources and the heritage of soviet regulating infrastructure of the Naryn-Syrdarya reservoir system have a profound impact on the environment and the competition for irrigation or energy sectors in the CA. For example, the Charvak reservoir was filled with water only by $50 \%$ in 2008 . This will put extra pressure on the water reservoirs that already accounts for $24 \%$ of irrigation water in Uzbekistan.

With the reduction of government financial investment portfolio in the rehabilitation and maintenance of hydraulic structures, it is urgent to adopt an innovative approach for reservoir sedimentation survey projects with the use of geoinformation technologies. We would like to propose the following recommendations to be used for the estimation of the sedimentation impacts on reservoirs.

1. New technologies and methods for the prediction of the water availability and loss of reservoir volume to sedimentation have proved to be cost-effective in reducing the number of personnel and time for such surveys by several folds based on the use of contour and mapping programs with interpolation techniques

2. Research must be carried out on the estimation of erosion and sedimentation yields on the watershed across Uzbekistan to develop a comprehensive database on the magnitude of erosion and sedimentation rates. Introduction of an Integrated Sediment Management Concept must be incorporated into the decision making processes in the early stages of the planning of the construction of new reservoirs, and active involvement of the research community into the decision making procedure will benefit to the sustainable use and 
management of both physical hydraulic infrastructure and consequently to the optimal use of the scarce water resources of Uzbekistan.

\section{Acknowledgements}

The authors would like to thank the French Embassy in Tashkent for supporting the FrenchUzbek cooperation in the field of water sciences. This study has also been supported by INTAS fellowship Nr. 04-83-3665 and by the French Ministry of Foreign Affairs via the Eiffel fellowship program No. 530909C. Special acknowledgements are expressed to the Bathymetric Center of the Uzbekistan Ministry of Agriculture and Water Resources. However, the views expressed in this paper do not necessarily reflect those of the funding agencies, and no official endorsement should be inferred from it. 


\section{REFERENCES}

Abdullaev I., De Fraiture Ch., Giordano M., Yakubov M. and Rasulov A. 2009, Agricultural water use and trade in Uzbekistan: Situation and potential impacts of market liberalization. Water Resources Development, Vol. 25, No. 1, pp. 47-63.

Alekseevskiy N. I., Berkovich K. M. and Chalov R. S. 2008, Erosion, sediment transportation and accumulation in rivers. International Journal of Sediment Research, No. 23, pp. 93105.

Altunin S. T. 1962 (in Russian), The rivers regulation. Publisher "Selkhozizdat", Moscow, Russia.

Althaus J. J. and De Cesare G. 2006, Reservoir sedimentation. Project ALPRESERV.

Sustainable Sediment Management in Alpine Reservoirs considering ecological and economic aspects. Vol.3/2006, Neubiberg. ISSN 1862-9644. -107p, http://www.alpreserv.eu

Annandale G. W. 1987, Reservoir sedimentation. Elsevier Science Publishers B.V., Amsterdam, the Netherlands.

Avakyan A. B., Saltankin V. P. and Sharapov V. A. 1987 (in Russian), Water reservoirs. Publisher "Misl”, Moscow, Russia.

Bathymetric Center. (in Uzbek) 2003, Estimation of Akdarya reservoir capacity using CEEDUCER, Uzbekistan Ministry of Agriculture and Water Resources, Tashkent, Uzbekistan.

Bobrovitskaya N. N. 2002, Erosion and sediment yield modeling in the former USSR. In: Summer W. and Walling D. E. (Eds). Modelling erosion, sediment transport and sediment yield. International Hydrological Programme. IHP-VI. Tech. Docs in Hydrology, No. 60. UNESCO, Paris, 2002, pp. 31-45.

Bobravitskaya N. N and Zubkova K. M. 1997, Improved methodology for the computation of normal annual yield of suspended sediments from rivers. Study of Erosion, River bed 
Deformation and Sediment Transport in River Basins as related to Natural and Manmade Changes. International Hydrological Programme. IHP-V. Tech. Docs in Hydrology, No. 10. UNESCO, Paris, 1997. pp. 92-103.

Brandt S. A. 2000, Classification of geomorphological effects downstream of dams. Catena, Vol. 40, pp. $375-401$.

Bruk S. 1985, Prediction methods. In: Bruk S (Ed), Methods of Computing Sedimentation in Lakes and Reservoirs. International Hydrological Programme, IHP-II Project, A.2.6.1.Panel, UNESCO, Paris, pp. 165-210.

Crosa G., Froebrich J., Nikolayenko V., Stefani F., Galli P. and Calamari D. 2006, Spatial and seasonal variations in the water quality of the Amu Darya River (Central Asia). Journal of Water Resources, No. 40, pp. 2237 - 2245. DOI:10.1016/j.watres.2006.04.004.

Evrard J. 1985, Technical and economic impact of reservoir sedimentation. In: S. Bruk (Editor), Methods of Computing Sedimentation in Lakes and Reservoirs. International Hydrological Programme, IHP-II Project, A.2.6.1.Panel, UNESCO, Paris, pp. 1-10. FAO (Food and Agriculture Organization of United Nations). http://www.fao.org Accessed on 15 November of 2007.

Furnans J. and Austin B. 2008, Hydrographic survey methods for determining reservoir volume. Environmental Modelling \& Software, No. 23, pp. 139-146. DOI:10.1016/j.envsoft.2007.05.011.

Gadalia A. and Motelica-Heino M. 2008, Role of the sediments in scavenging inorganic contaminants in the Syr Daria River and the Small Aral Sea (Kazakhstan). Proceedings of International Symposium on Sediment Management In: Abriak N.E., Amidot D. and Zentar R. (Eds), Lille, France, pp. 335 - 342.

Gadalia A., Motelica-Heino M., Serra H., Abou Akar A., Jouin F. and Charpy A. 2005, Inorganic pollutants of the Syr-Daria River (Kazakh Priaralie). Thetys Geographic Research I, No. 25, pp. 79-92. 
Golosov V., Sidorchuk A. and Walling D.E. 2008, Nikolay I. Makkaveev and the development of Fluvial Geomorphology in Russia and the former Soviet Union. Journal Catena, No. 73, pp. 146-150. DOI:10.1016/j.catena.2007.10.003.

Graf W. L. 2005, Geomorphology and American dams: The scientific, social and economic context. Geomorphology, Vo. 71, pp. 3-26.

Hagg W., Braun L. N., Kuhn M. and Nesgaard T. I. 2007, Modelling of hydrological response to climate change in glacierized Central Asian catchments. Journal of Hydrology, No. 332, pp. 40-53.

Heaven S., Koloskov G. B., Lock A. C. and Tanton T. W. 2002, Water Resources Management in the Aral Basin: a River Basin Management Model for the Syr Darya. Journal of Irrigation and Drainage, No. 51, pp. 109-118. DOI: 10.1002/Ird.42.

Herzog J. and Bradshaw A. 2005, A method for comparing bathymetric survey data to determine changes in sediment elevation. The Hydrographic Journal, No. 18 (October), pp. 3-9. IAMO (Leibniz Institute of Agricultural Development in Central and Eastern Europe). 2008, Continuity and change: Land and water use reforms in rural Uzbekistan: Socioeconomic and legal analyses for the region Khorezm. Vol.43, http://www.aimo.de/dok/sr_vol43.pdf

Ibragimov N., Evett S. R., Esanbekov Y., Kamilov B. S., Mirzaev L. and Lamers J. 2007, Water use efficiency of irrigated cotton in Uzbekistan under drip and furrow irrigation. Agricultural Water Management, No. 90, pp. 112-120.

Ibad-Zade U. A. 1989 (in Russian), Sediment regime of rivers. Publisher "Stroyizdat", Moscow, Russia.

ICG (International Crisis Group). 2002, Central Asia: Water and conflict. ICG Asia Report 34 (30 May), Osh/Brussels.

ICOLD (International Commission on Large Dams). http://www.icold-cigb.org. The site was accessed on 15 June, 2008. 
IHO (International Hydrographic Organization). 2005, Manual on Hydrography. Publ. No. M-

13. $1^{\text {st }}$ Ed. Monaco, May.

Irrigation of Uzbekistan: Irrigation development in a complex of production forces of

Uzbekistan. 1975, Vol. I. Publisher "Fan", Tashkent, Uzbekistan.

ICWC (Interstate Commission for Water Coordination). 2004, Strategic Planning and

Sustainable Water Development Management in Central Asia. Publ. No. 8. Training Center of ICWC, Tashkent, Uzbekistan

Ismagilov H. A. 1997, Fluvial sediment transport in the arid regions of Central Asia. Study of

Erosion, River bed Deformation and Sediment Transport in River Basins as Related to

Natural and Man-made Changes. International Hydrological Programme. IHP-V. Tech.

Docs in Hydrology, No. 10. UNESCO, Paris, 1997. pp. 165-173.

Karaushev A. V. 1977 (in Russian), Theory and methods for riverine sediment calculation.

Publisher "Gidrometeoizdat”, Leningrad, Russia.

Karaushev A. V. 1969 (in Russian), Riverine hydraulics. Publisher “Gidrometeoizdat”, Leningrad, Russia.

Kazbekov J., Rakhmatullaev Sh., Huneau F. and Le Coustumer P. 2007, Types and hydrogeologic features of surface and groundwater interactions in Uzbekistan. Paper presented at $35^{\text {th }}$ International Association of Hydrogeologists Congress on Groundwater and Ecosystems, Lisbon, Portugal, CD of the Conference Proceedings, ISBN978-989-95297-3-1.

Khorst M. 2001, Inventory of water users and water usage on typical irrigated areas, subcommand to farm canals. Consultant report, Project Adoption of Best Practices (Project Code: 312310). International Water Management Institute.

Knoblauch H. 2006, Sediment management methods - Technical and legal aspects. Project ALPRESERV. Sustainable Sediment Management in Alpine Reservoirs considering 
ecological and economic aspects. Vol. 4/2006, Neubiberg. ISSN 1862-9644. - 125p.

\section{http://www.alpreserv.eu}

Lapshenkov V. S. 1959 (in Russian), Forecast issues of sediment accumulation in backwater of hydraulic structures. $\mathrm{PhD}$ thesis. Central Asian Research Institute for Irrigation, Tashkent, Uzbekistan.

Lioubimtseva E., Cole R., Adams J.M. and Kapustin G. 2005, Impacts of climate and land-cover changes in arid lands of Central Asia. Journal of Arid Environments, No. 62, pp. 285308. DOI:10.1016/j.jaridenv.2004.11.005.

Mahmood K. 1987, Reservoir sedimentation. Impact, extent and mitigation. WTP 71, ISBN 08213-0952-8. World Bank, Washington, D.C.

McPherson K.R. and Harmon J.G. 1998, Storage capacity and sedimentation of Loch Lomond reservoir. U.S. Geological Survey water-resources investigations Report 00-4016, Santa Cruz, California.

Morris G. L. and Fan J. 1998, Reservoir sedimentation handbook, design and management of dams, reservoirs and watershed for sustainable use. New York: McGraw-Hill.

Mukhamedov A. M. 1976 (in Russian), Operation of low head hydraulic schemes on rivers with sediment transport. Publisher "Fan", Tashkent, Uzbekistan.

Naisen J. and Lingyan F. 1998, Problems of reservoir sedimentation in China. Chinese

Geographical Science, Vol. 8, No. 2, pp.117- 125.

Nezlin N. P., Kostianoy A. G. and Lebedev S. A. 2004, Interannual variations of the discharge of Amu Darya and Syr Darya estimated from global atmospheric precipitation. Journal of Marine Systems, No. 47, pp. 67-75. DOI:10.1016/j.jmarsys.2003.12.009.

Nikitin A. M. 1991 (in Russian), Hydrological regime of lakes and water reservoirs in USSR: Water reservoirs of Central Asia. Publisher "Hydrometeoizdat", Leningrad, Russia.

O’Hara S. L. 2000, Lessons from the past: water management in Central Asia. Water Policy, No. 2, pp. 365-384. PII: 1366-7017(00)00010-6. 
Palmieri A., Shah F. and Dinar A. 2001, Economics of reservoir sedimentation and sustainable management of dams. Journal of Environmental Management, No. 61: 149-163.

Popov I. V. 1977 (in Russian), Tales of river channel processes. Publisher "Gidrometeoizdat”, Leningrad, Russia.

Rakhmatullaev, S., Marache, A., Huneau, F., Le Coustumer, P., Bakiev, M., Motelica-Heino, M. 2011. Geostatistical approach for the assessment of the water reservoir capacity in arid regions: A case study of the Akdarya reservoir, Uzbekistan. Environmental Earth Sciences, 63, 447-460. DOI: 10.1007/s12665-010-0711-3

Rakhmatullaev, S., Huneau, F., Kazbekov, J., Le Coustumer, P., Jumanov, J., El Oifi, B., Motelica-Heino, M., Hrkal, Z. 2009, Groundwater resources use and management in the Amu Darya River Basin (Central Asia). Environmental Earth Sciences, 59, 1183-1193 DOI:10.1007/s12665-009-0107-4.

Rakhmatullaev S., Huneau F., Kazbekov J. and Le Coustumer P. 2008a, Groundwater resources and uses in Central Asia: Case study of Amu Darya river basin. Paper presented at $36^{\text {th }}$ International Association of Hydrogeologists Congress on Integrating Groundwater Science and Human Well-being, Toyoma, Japan, 26 October - 1 November 2008. Rakhmatullaev S. A., Bakiev M. R., Marache A. and Le Coustumer P. 2008b (in Russian), Geostatistical approach in estimation of sedimentation: A case study of Akdarya reservoir. Journal of Hydrotechnical construction, No. 6 (July), pp. 32-35.

Rakhmatullaev S. and Le Coustumer P. 2006 (in Russian), Sedimentation dynamics of Akdarya reservoir. Proceedings of National Conference on Contemporary Hydraulic Structures Safety Assurance, Tashkent, Uzbekistan, pp. 72-75.

Revenga C., Murray S., Abramovitz J. and Hammond A. 1998, Watersheds of the World: Ecological Value and Vulnerability. Washington, DC: World Resources Institute. 
Saiko T. A. and Zonn I. S. 2000, Irrigation expansion and dynamics of desertification in the Circum-Aral region of Central Asia. Journal of Applied Geography, No. 20, pp. 349367. PII: S01 43 -6228(00)00014-X.

Sattarov M. A., Eshmirzoyev I. E. and Rakhimov F. 2006, Problems of estimation and rational use of water resources of Aral Sea basin. Proceedings of International Conference on Extreme Hydrological Events in Aral and Caspian Sea Region. Moscow, Russia, pp. 269-274.

SedNet (the European Sediment Research Network). 2004, Contaminated sediments in European River Basins. Final Report. http://www.SedNet.org. - 46p.

Schlüter M., Savitsky A. G., McKinney D. C. and Lieth H. 2005, Optimizing long-term water allocation in the Amudarya River delta: a water management model for ecological impact assessment. Journal of Environmental Modelling \& Software, No. 20, pp. 529545. DOI:10.1016/j.envsoft.2004.03.005.

Shamov G. I. 1954 (in Russian), Riverine sediments: River channel and their catchment erosion. Publisher "Gidrometeopizdat", Leningrad, Russia.

Shvartsman A. I. 1994, Reservoirs and sediment management. In: S. Bruk, H. Zebidi, (Eds), Proceedings of Workshop on Reservoir Sedimentation. International Hydrological Programme, 16-20 May 1994, St. Petersburg, Russia. IHP-IV Project H-1-2, UNESCO, Paris, pp. 250-259.

Shultz V. 1949 (in Russian), Central Asian rivers. Publisher "Nauka”, Moscow, Russia. Skrylnikov V. A., Keberle S. I. and Beleskov B. I. 1987 (in Russian), Improvement of reservoir operation efficiency. Publisher "Mehnat”, Tashkent, Uzbekistan.

Smalley I. J., Mavlyanova N. G., Rakhmatullaev Kh. L., Shermatov M. Sh., Machalett B., O'Hara D. K. and Jefferson I. F. 2006, The formation of loess deposits in the Tashkent region and parts of Central Asia; and problems with irrigation, hydrocollapse and soil erosion. Quaternary International, No.152-153, pp. 59-69. 
Sternberg R. 2006, Damming the river: A changing perspective on altering nature. Renewable and Sustainable Energy Reviews, No. 10, pp. 165-197.

Syvitski J.P. M. 2003, Supply and flux of sediment along hydrological pathways: Research of the $21^{\text {st }}$ century. Global and Planetary Change, No. 39, pp. 1-11.

Talipov G. A. 1992 (in Russian), Land resources of Uzbekistan and their rational use. Publisher “Uzinformagroprom”, Tashkent, Uzbekistan.

Tookey D. L. 2007, The environment, security and regional cooperation in Central Asia. Journal of Communist and Post-Communist Studies, No. 40, pp. 191-208.

DOI:10.1016/j.postcomstud.2007.03.004.

UNEP (United Nations Environmental Programme). 2005, Severskiy I., Chervanyov I.,

Ponomarenko Y., Novikova N. M., Miagkov S. V., Rautalahti E. and D. Daler (Eds).

Global International Waters Assessment Aral Sea, GIWA Regional assessment 24.

University of Kalmar, Kalmar, Sweden.

UNDP (United Nations Development Program). 2007, Water, critical resource for Uzbekistan's future. UNDP, Tashkent, Uzbekistan.

UNESCO (United Nations Educational, Scientific and Cultural Organization). 2000, Waterrelated vision for the Aral sea basin for the year 2025. Paris, France: UNESCO.

USACE (United States Army Corps of Engineers). 2001, Hydrographic Surveying Engineering manual. Engineering and Design, 1110-2-1003. Washington DC. January.

Velikanov M. A. 1955 (in Russian), Streamflow dynamics: Sediments and river channel. Vol. 2, $3^{\text {rd }}$ Ed. Publisher "Gozizdat texniko-teoreticheskoy lit”, Moscow, Russia.

Vörösmarty Ch. J., Meybeck M., Fekete B., Sharmad K., Green P. and Syvitski J. M. P. 2003, Anthropogenic sediment retention: major global impact from registered river impoundments. Global and Planetary Change, No. 39, pp. 169-190. DOI: 10.1016/S0921-8181(03)00023-7. 
Vuglinsky V. S. 1991 (in Russian), Water resources and water balance of large reservoirs of USSR. Publisher “Gidrometeoizdat”, Leningrad, Russia.

WASER (World Association on Sedimentation and Erosion Research). http://www.waser.ch . The site accessed on August 5, 2008.

Walling D. E. 2006, Human impact on land-ocean sediment transfer by the world's rivers. Geomorphology, No. 79, pp. 192-216.

Weinthal E. 2006, Water conflict and cooperation in Central Asia. Background paper In: UN Human Development Report 2006, Nicholas School of the Environment and Earth Sciences, Duke University.

White W. R. 2005, A review of current knowledge. World water storage in main-made reservoirs. Foundation for Water Research, FR/R0012, UK, http://www.fwr.org Wohl E. and Rathburn S. 2003, Mitigation of sedimentation hazards downstream from reservoirs. International Journal of Sediment Research, Vol. 18, No. 2, pp. 97-106. WCD (World Commission on Dams) 2000, Dams and Development: A New Framework for Decision-Making. Earthscan Publication, London, ISBN 1-85383-797-0.

World Bank. 2005, Drought: Management and mitigation assessment (for Central Asia and the Caucasus). Report No.31998-ECA.

World Bank. 2003, Irrigation in Central Asia: Social, economic and environmental considerations. www.worldbank.org/eca/environment. Accessed on 12 January 2008.

Ximing C., McKinney D. C. and Rosegrant M. W. 2003, Sustainability analysis for irrigation water management in the Aral Sea region. Agricultural Systems, No. 76, pp. 1043-1066. Yang X. 2003, Manual on sediment management and measurement. World Meteorological Organization, Operational Hydrology Report No. 47, WMO-No. 948. Secretariat of the World Meteorological Organization-Geneva, Switzerland. 


\section{LIST OF TABLES}

Table 1. Construction of water reservoirs in the Central Asian region (Skrylnikov et al., 1987)

Table 2. Distribution of reservoirs in Central Asia by country and their share to irrigation (Food and Agriculture Organization of United Nations)

Table 3. Distribution of water reservoirs in Uzbekistan by administrative boundaries (United Nations Development Program, 2007)

Table 4. Characteristics of the large water reservoirs in Uzbekistan (Bathymetric Center of the Ministry of Agriculture and Water Resources of the Republic of Uzbekistan, 2003)

Table 5. 16 Reservoirs in Uzbekistan where sedimentation estimation was carried out by new technologies (Bathymetric Center of the Ministry of Agriculture and Water Resources of the Republic of Uzbekistan, 2003) 


\section{FIGURE CAPTIONS}

Fig. 1. Schematic location of main water reservoirs and their volume capacities in Central Asia (adopted and modified from Nikitin, 1991)

Fig. 2. Development of irrigated land in Central Asia countries, 1913-2003 (Sattarov et al., 2006)

* Data for Kazakhstan from FAO, 2007

Fig. 3. Location of main reservoirs in Central Asia

Fig. 4. Trends of irrigated land and specific water intake for irrigation in Uzbekistan, 1990-2020 (after United Nations Development Program 2007)

Fig. 5. Origin of irrigation water in Uzbekistan, 1994 (Food and Agriculture Organization of United Nations 2007)

Fig. 6. Rate of reservoir construction in numbers and gross volume capacity in the twentieth century in Uzbekistan

Fig. 7. Area affected by water, wind and irrigation erosion in Uzbekistan, 1968-1989 (Talipov, 1992) 
Table 1. Construction of water reservoirs in the Central Asian region (Skrylnikov et al., 1987)

\begin{tabular}{lccccccc}
\hline Parameter & $\begin{array}{c}\text { Prior } \\
\mathbf{1 9 1 8}\end{array}$ & $\begin{array}{c}\mathbf{1 9 1 9 -} \\
\mathbf{1 9 4 0}\end{array}$ & $\begin{array}{c}\mathbf{1 9 4 1 -} \\
\mathbf{1 9 5 0}\end{array}$ & $\begin{array}{c}\mathbf{1 9 5 1 -} \\
\mathbf{1 9 6 0}\end{array}$ & $\begin{array}{c}\mathbf{1 9 6 1 -} \\
\mathbf{1 9 7 0}\end{array}$ & $\begin{array}{c}\mathbf{1 9 7 1 -} \\
\mathbf{1 9 8 0}\end{array}$ & $\begin{array}{c}\mathbf{1 9 8 1 -} \\
\mathbf{1 9 8 5}\end{array}$ \\
\hline No. of reservoirs & 5 & 2 & 4 & 17 & 21 & 19 & 7 \\
\hline $\begin{array}{l}\text { Volume capacity } \\
\left(\mathrm{km}^{3}\right)\end{array}$ & 0.172 & 0.167 & 1.25 & 7.23 & 4.68 & 35.0 & 0.89 \\
\hline $\begin{array}{l}\text { Cumulative } \\
\begin{array}{l}\text { Volume capacity } \\
\left(\mathrm{km}^{3}\right)\end{array}\end{array}$ & 0.17 & 0.34 & 1.59 & 8.82 & 13.45 & 48.45 & 49.34 \\
\hline
\end{tabular}


Table 2. Distribution of reservoirs in Central Asia by country and their share to irrigation (Food and Agriculture Organization of United Nations)

\begin{tabular}{lccc}
\hline Country & $\begin{array}{c}\text { Total reservoir } \\
\text { volume capacity } \\
\left(\mathbf{k m}^{\mathbf{3}} \mathbf{)}^{\mathbf{a}}\right.\end{array}$ & $\begin{array}{c}\text { Number of } \\
\text { reservoirs }\end{array}$ & $\begin{array}{c}\text { Irrigation water } \\
\text { from reservoirs } \\
(\mathbf{\%})^{\mathbf{b}}\end{array}$ \\
\hline Kazakhstan & 88.8 & 180 & 32 \\
Kyrgyzstan & 23.5 & 18 & 13 \\
Tajikistan & 29 & 19 & 28 \\
Turkmenistan & 2.89 & 18 & 54 \\
Uzbekistan & 19 & 55 & 24 \\
\hline Total in CA & $\mathbf{1 6 3 . 1 9}$ & $\mathbf{2 9 0}$ & \\
\hline
\end{tabular}

${ }^{\mathrm{a}}$ FAO, 2007; ${ }^{\mathrm{b}}$ FAO, 1994. 
Table 3. Distribution of water reservoirs in Uzbekistan by administrative boundaries (United Nations Development Program, 2007)

\begin{tabular}{|c|c|c|c|c|c|}
\hline Province & Number & $\begin{array}{c}\text { Useful } \\
\text { Volume } \\
\text { Capacity } \\
\left(\mathbf{k m}^{3}\right)\end{array}$ & Province & Number & $\begin{array}{c}\text { Useful } \\
\text { Volume } \\
\text { Capacity } \\
\left(\mathrm{km}^{3}\right)\end{array}$ \\
\hline \multicolumn{3}{|c|}{ Amи Darya River Basin } & \multicolumn{3}{|c|}{ Syr Darya River Basin } \\
\hline Khorezm & 1 & 4.5 & Andijan & 3 & 1.7 \\
\hline Kashkadarya & 14 & 2.3 & Tashkent & 5 & 1.9 \\
\hline Samarkand & 7 & 1.1 & Fergana & 4 & 0.25 \\
\hline Surkhandarya & 4 & 0.9 & Namangan & 7 & 0.23 \\
\hline Navoi & 2 & 0.8 & Jizzak & 4 & 0.18 \\
\hline Bukhara & 2 & 0.4 & Syrdarya & 2 & 0.01 \\
\hline Total & 30 & 10.1 & & 25 & 4.45 \\
\hline
\end{tabular}


Table 4. Characteristics of the large water reservoirs in Uzbekistan (Bathymetric Center of the Ministry of Agriculture and Water Resources of the Republic of Uzbekistan, 2003)

\begin{tabular}{llcccc}
\hline Reservoir & River Basin & $\begin{array}{c}\text { Started to } \\
\text { operate } \\
(\text { Year })\end{array}$ & $\begin{array}{c}\text { Dam } \\
\text { height } \\
(\mathbf{m})\end{array}$ & $\begin{array}{c}\text { Total volume } \\
\text { capacity } \\
\left(\mathbf{k m}^{\mathbf{3}}\right)\end{array}$ & $\begin{array}{c}\text { Surface } \\
\mathbf{a r e a} \\
\mathbf{k m}^{\mathbf{2}} \mathbf{)}\end{array}$ \\
\hline Tuyamuin $^{\mathrm{a}}$ & Amu Darya & 1980 & 34 & 7.80 & 650 \\
Charvak & Chirchiq & 1977 & 168 & 2.0 & 40.3 \\
Andijan & Kora Darya & 1970 & 121 & 1.90 & 55.5 \\
Tallimarjan & Amu Darya & 1985 & 36 & 1.52 & 77.3 \\
Tudakul & Amu Darya & 1983 & 12 & 1.20 & 162 \\
Kattakurgan & Zerafshan & 1953 & 31.2 & 0.82 & 84.5 \\
Janubiy & Surkhan Darya & 1967 & 30 & 0.80 & 65 \\
Surhan & & & & & \\
Chimkurgan & Kashka Darya & 1963 & 33 & 0.50 & 49.2 \\
Kuyimazar & Amu Darya & 1958 & 23.5 & 0.32 & 178.5 \\
\hline
\end{tabular}

a Tuyamuin is composed of four reservoirs: 1) Ruslovoy with volume capacity $\left.\left(2.34 \mathrm{~km}^{3}\right) ; 2\right)$ Sultansanjar with volume capacity $\left.\left(2.69 \mathrm{~km}^{3}\right) ; 3\right)$ Kaparas with volume capacity $\left.\left(0.96 \mathrm{~km}^{3}\right) ; 4\right)$ Koshbulak with volume capacity $\left(1.81 \mathrm{~km}^{3}\right)$. 
Table 5. 16 Reservoirs in Uzbekistan where sedimentation estimation was carried out by new technologies (Bathymetric Center of the Ministry of Agriculture and Water Resources of the Republic of Uzbekistan, 2003)

\begin{tabular}{lccccc}
\hline Reservoir & $\begin{array}{c}\text { Initial } \\
\text { Volume } \\
\left(\mathbf{M m}^{\mathbf{3}}\right)\end{array}$ & $\begin{array}{c}\text { Silted } \\
\text { volume } \\
(\mathbf{\%})\end{array}$ & $\begin{array}{c}\text { Initial } \\
\text { Volume } \\
\left(\mathbf{M m}^{\mathbf{3}}\right)\end{array}$ & $\begin{array}{c}\text { Silted } \\
\text { Volume } \\
(\boldsymbol{\%})\end{array}$ & $\begin{array}{c}\text { Started to } \\
\text { operate } \\
(\text { Year })\end{array}$ \\
\hline Total Volume Capacity & Dead Volume Capacity & \\
\hline Tashkent & 250 & 16.9 & 26 & 76.3 & 1962 \\
Janubiy & 1525 & 3.9 & 125 & 2.23 & 1985 \\
Surkhandarya & 800 & 37 & 100 & 78.7 & 1967 \\
Kuyimazar & 310 & 11.2 & 47 & 6.7 & 1958 \\
Tudakul & 1200 & 13.7 & 600 & 9.6 & 1983 \\
Akhangaran & 198 & 4.8 & 13 & 27.7 & 1969 \\
Andijan & 1900 & 13.4 & 150 & 39.2 & 1970 \\
Jizzak & 100 & 19.9 & 4 & 96.2 & 1966 \\
Kattakurgan & 900 & 22.5 & 24 & 87 & 1953 \\
Tupalang & 100 & 16.6 & 8.79 & 88.4 & 1992 \\
Khissarak & 170 & 13.2 & 8.4 & 100 & 1985 \\
Chimkurgan & 500 & 22.7 & 50 & 31.8 & 1963 \\
Pachkamar & 260 & 25.9 & 10 & 99.8 & 1967 \\
Akdarya & 112.5 & 17.2 & 2.5 & 41.6 & 1984 \\
Ruslovoy & 2340 & 44.9 & 270 & 86.5 & 1980 \\
Kaparas & 960 & 1.9 & 410 & 1.65 & 1983 \\
\hline Average & & $\mathbf{1 7 . 8}$ & & $\mathbf{5 4 . 6}$ & \\
\hline
\end{tabular}


Fig. 1.

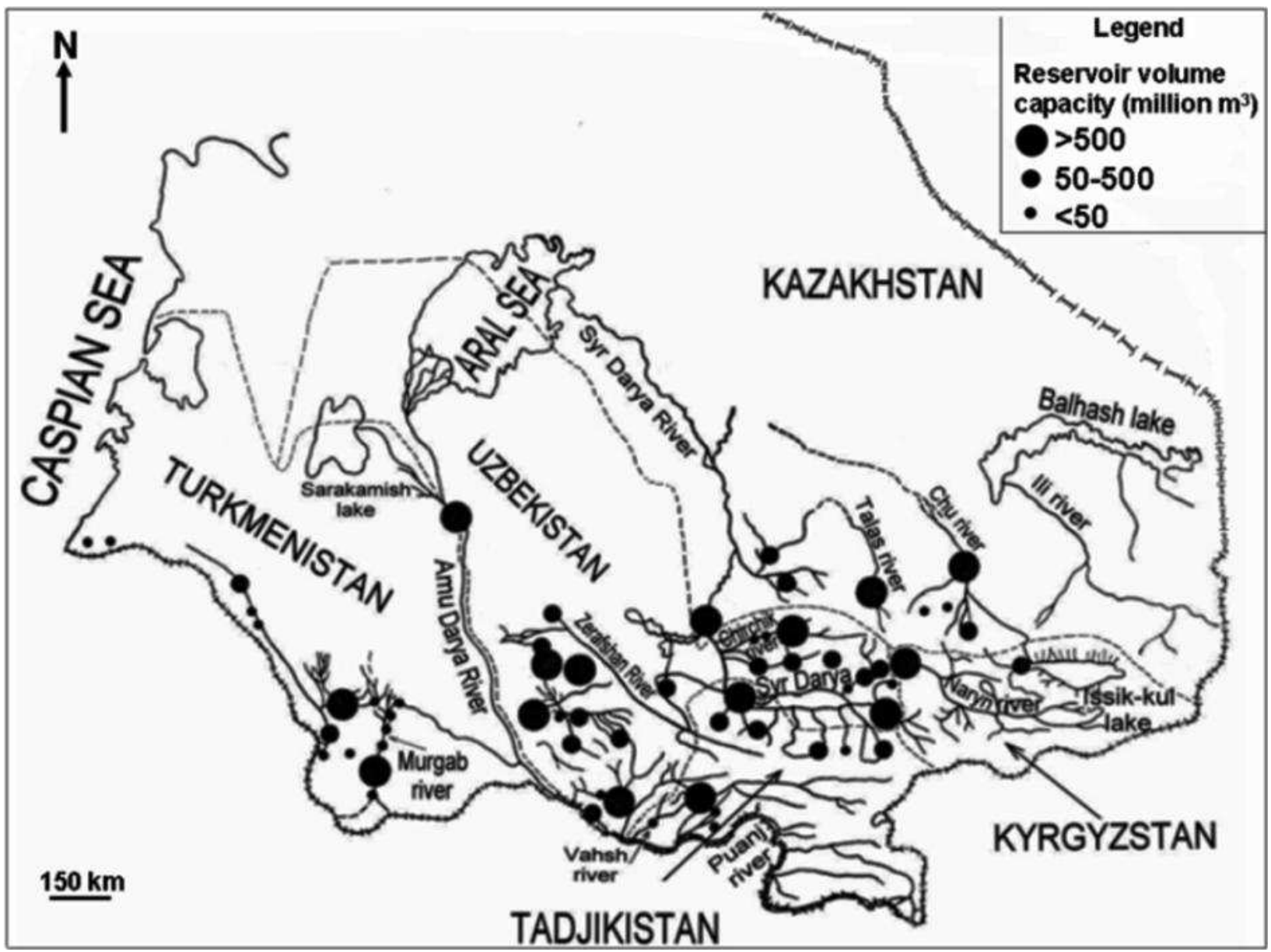


Fig. 2.

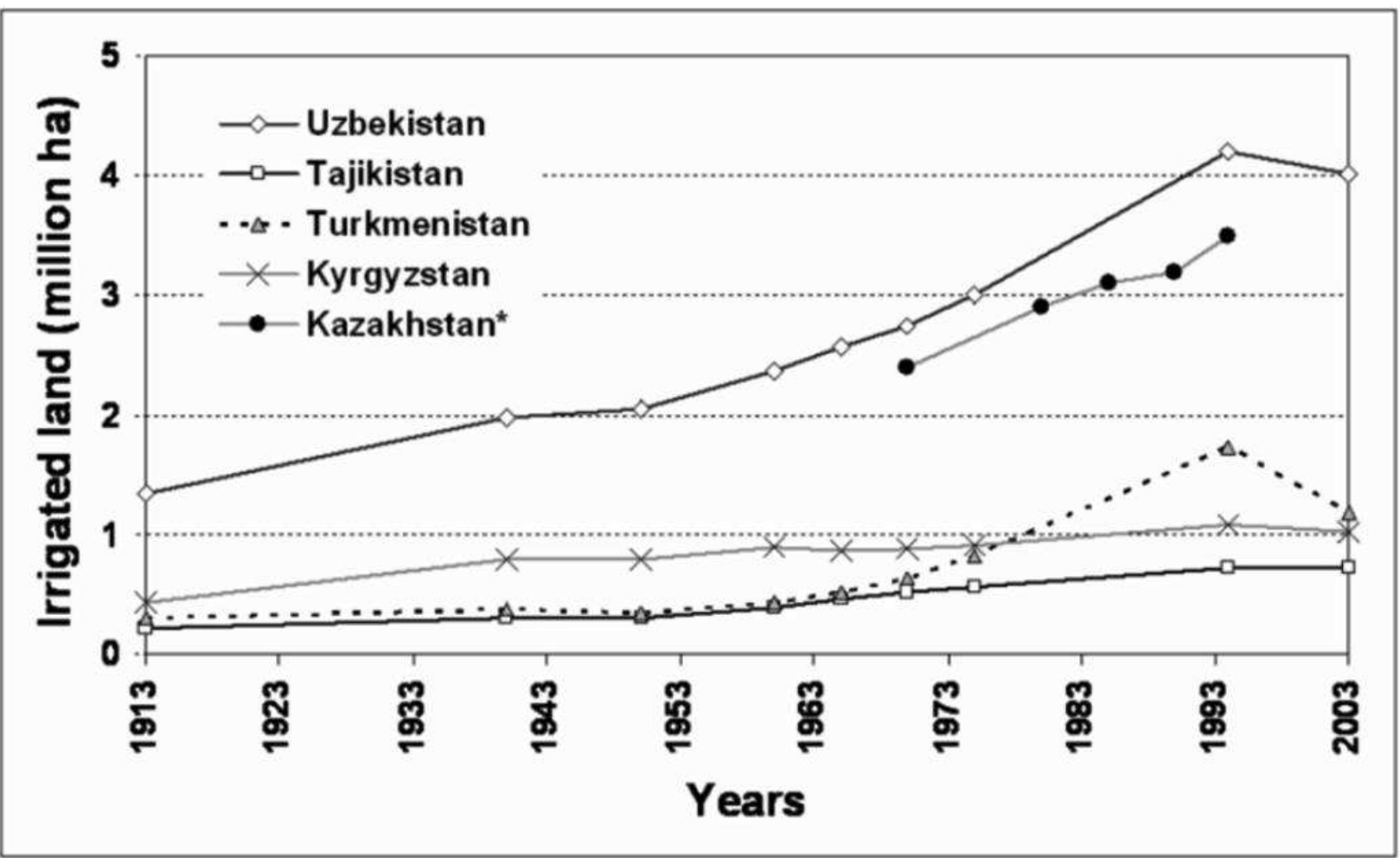


Fig. 3.

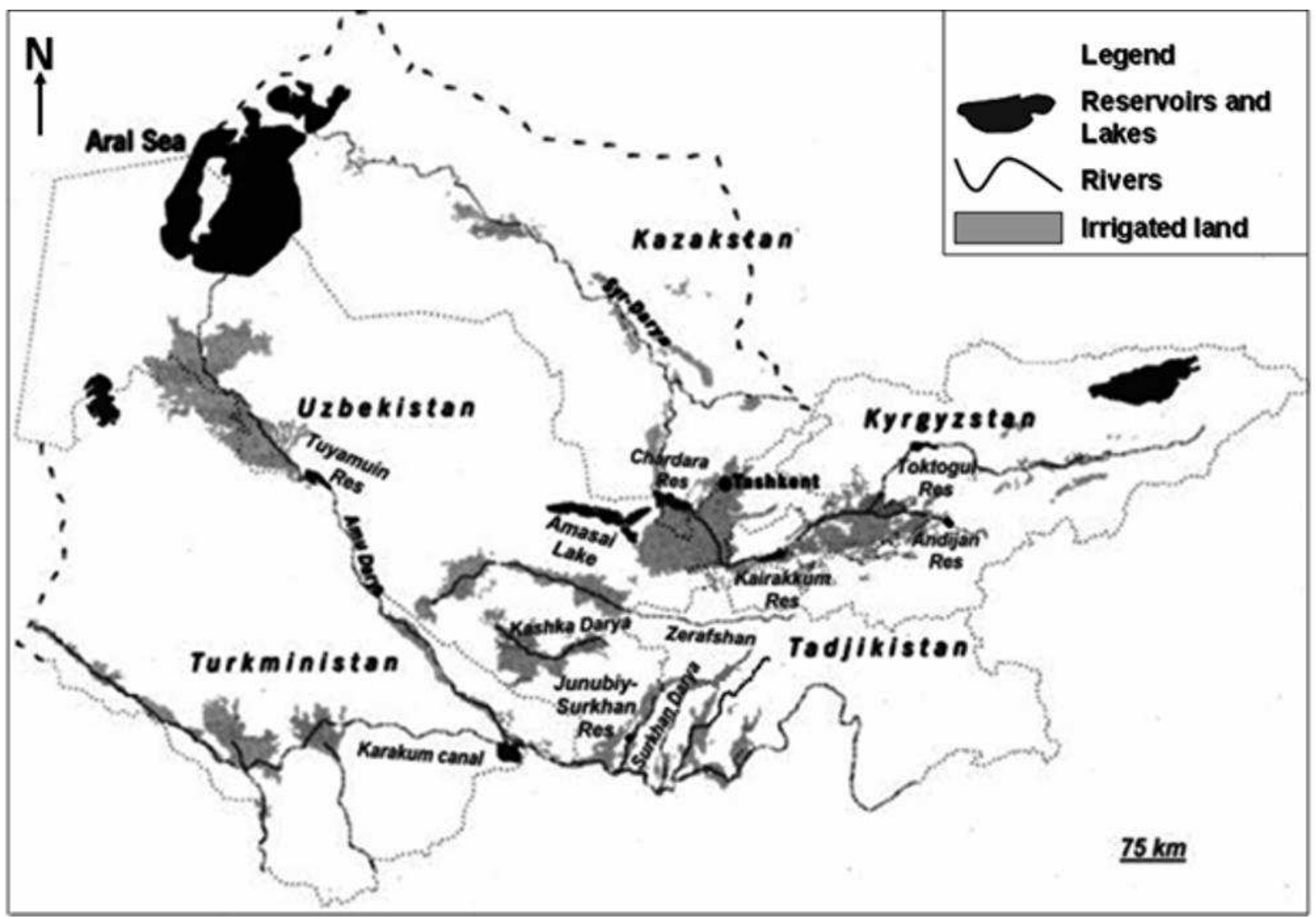


Fig. 4.

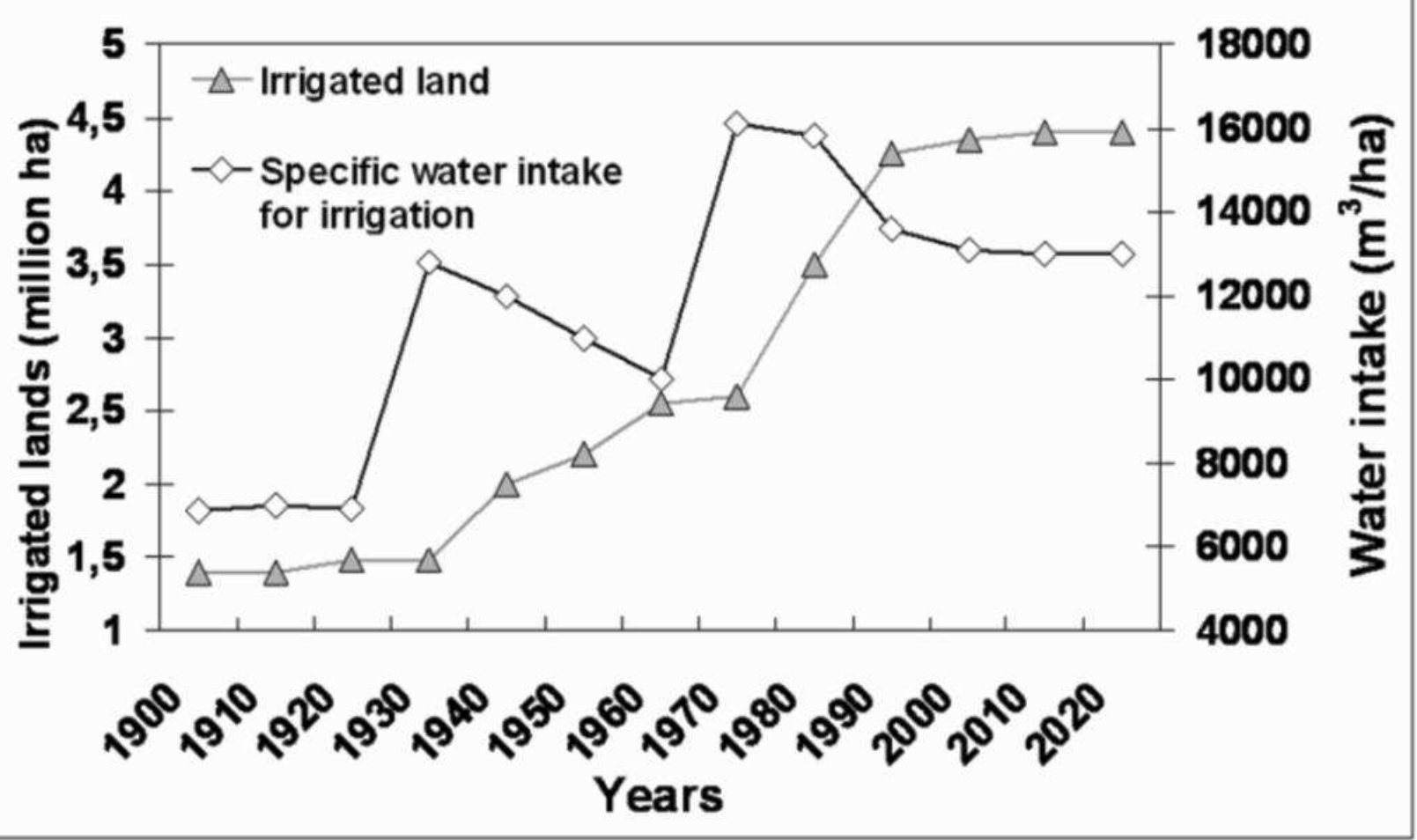


Fig. 5.

\section{Total irrigated land: 4280600 ha (1994)}

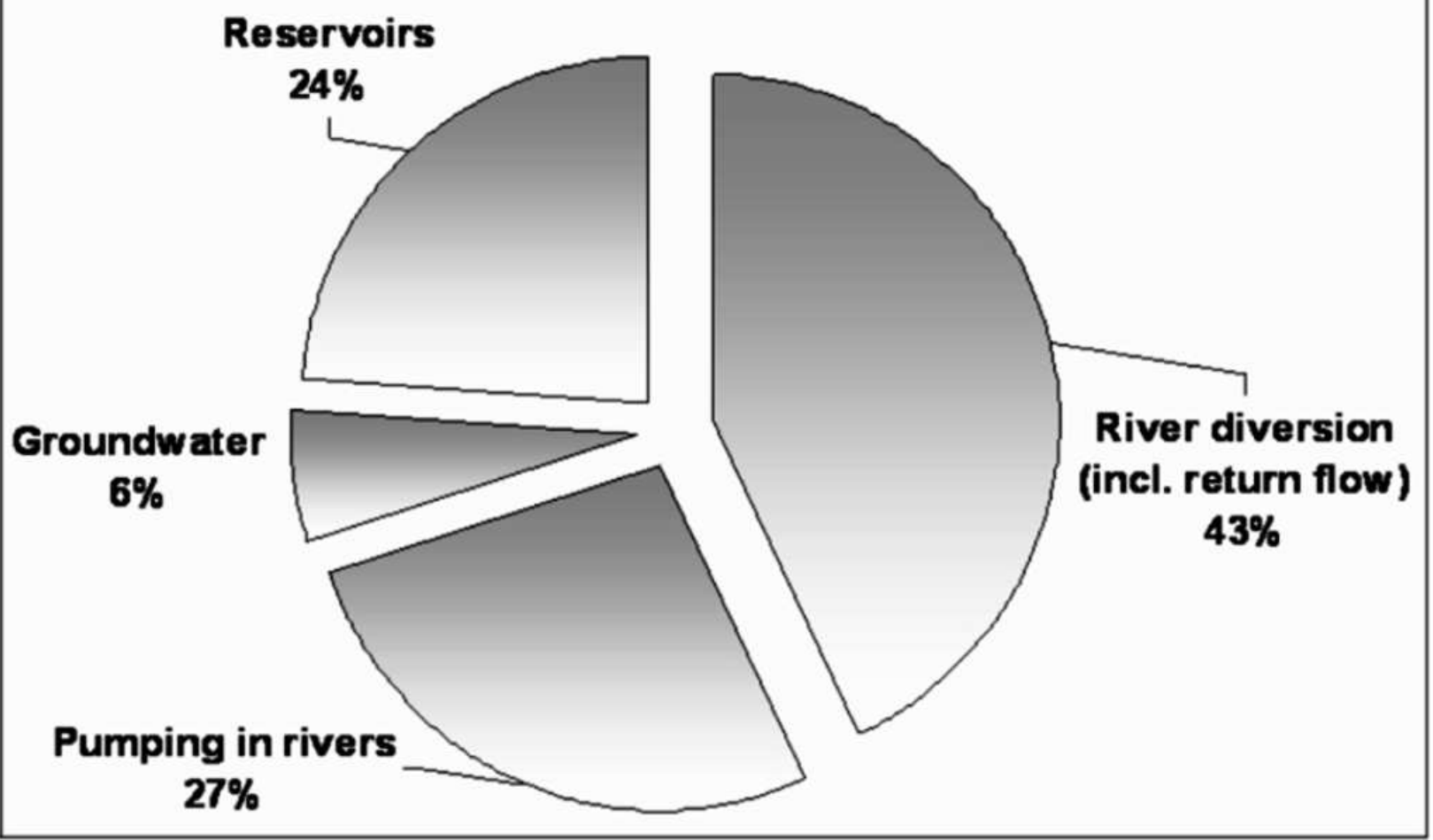


Fig. 6.

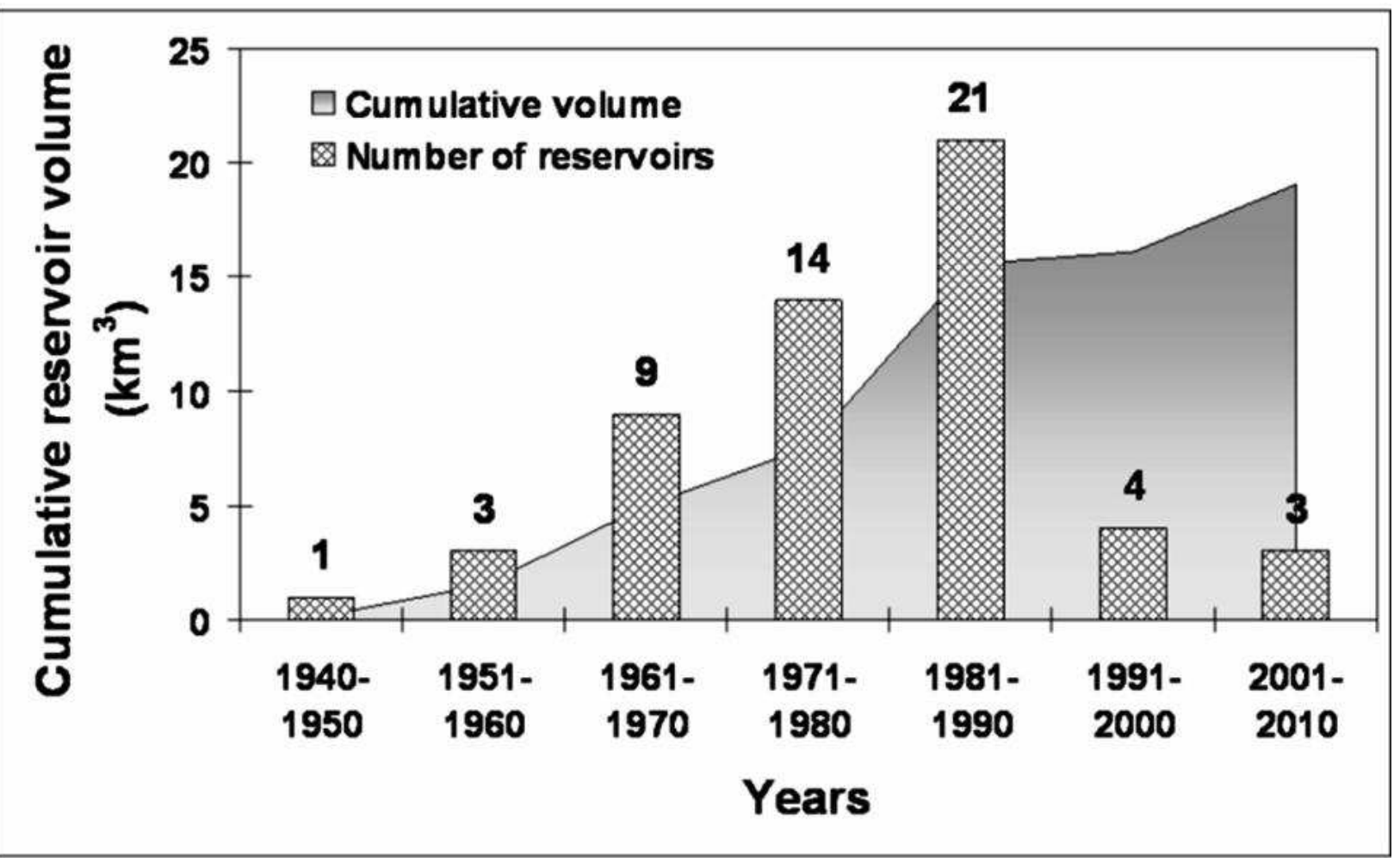


Fig. 7.

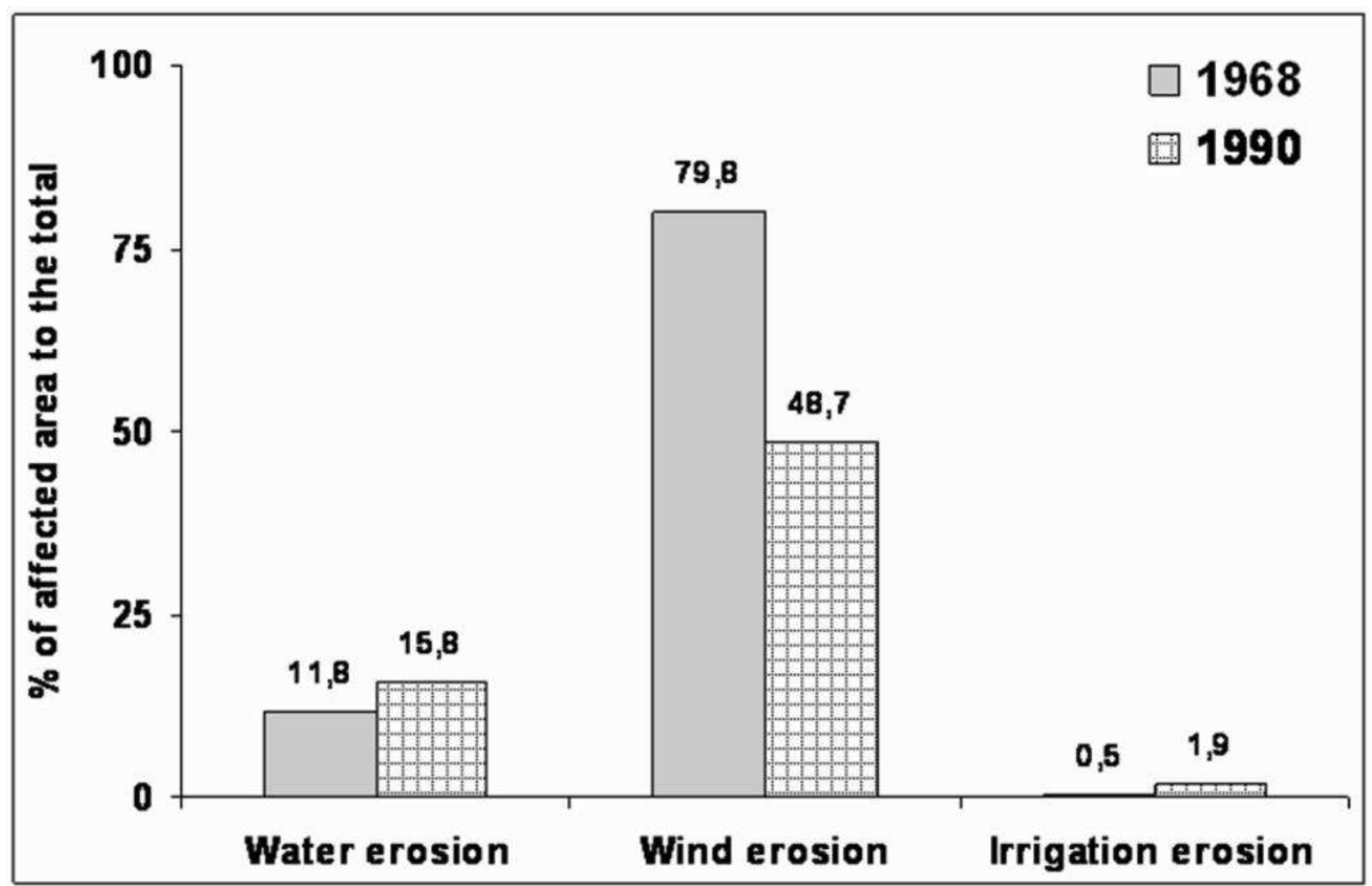

